\title{
Associations between antioxidants and all-cause mortality among US adults with obstructive lung function
}

\author{
Earl S. Ford ${ }^{1 *}$, Chaoyang $\mathrm{Li}^{2}$, Timothy J. Cunningham ${ }^{1}$ and Janet B. Croft ${ }^{1}$ \\ ${ }^{1}$ Division of Population Health, National Center for Chronic Disease Prevention and Health Promotion, Centers for Disease \\ Control and Prevention, 4770 Buford Highway, MS F78, Atlanta, GA 30341, USA \\ ${ }^{2}$ Division of Environmental Hazards and Health Effects, National Center for Environmental Health, Centers for Disease \\ Control and Prevention, Atlanta, GA, USA
}

(Submitted 10 March 2014 - Final revision received 2 July 2014 - Accepted 31 July 2014 - First published online 15 October 2014)

\begin{abstract}
Chronic obstructive pulmonary disease is characterised by oxidative stress, but little is known about the associations between antioxidant status and all-cause mortality in adults with this disease. The objective of the present study was to examine the prospective associations between concentrations of $\alpha$ - and $\beta$-carotene, $\beta$-cryptoxanthin, lutein/zeaxanthin, lycopene, Se, vitamin $\mathrm{C}$ and $\alpha$-tocopherol and all-cause mortality among US adults with obstructive lung function. Data collected from 1492 adults aged $20-79$ years with obstructive lung function in the National Health and Nutrition Examination Survey III (1988-94) were used. Through 2006, 629 deaths were identified during a median follow-up period of 14 years. After adjustment for demographic variables, the concentrations of the following antioxidants modelled as continuous variables were found to be inversely associated with all-cause mortality among adults with obstructive lung function: $\alpha$-carotene $(P=0.037) ; \beta$-carotene $(P=0.022)$; cryptoxanthin $(P=0.022)$; lutein/zeaxanthin $(P=0.004)$; total carotenoids $(P=0.001)$; vitamin $C(P<0.001)$. In maximally adjusted models, only the concentrations of lycopene $(P=0.013)$ and vitamin $C(P=0.046)$ were found to be significantly and inversely associated with all-cause mortality. No effect modification by sex was detected, but the association between lutein/zeaxanthin concentrations and all-cause mortality varied by smoking status $\left(P_{\text {interaction }}=0.048\right)$. The concentrations of lycopene and vitamin $\mathrm{C}$ were inversely associated with all-cause mortality in this cohort of adults with obstructive lung function.
\end{abstract}

Key words: Antioxidants: Chronic obstructive pulmonary disease: Mortality

Chronic obstructive pulmonary disease (COPD) remains a potent public health problem in the USA and globally ${ }^{(1,2)}$. After decades of increased mortality from COPD in the USA, the rate of mortality has stabilised since $2000^{(3)}$. Although the prevalence of smoking is the chief driver of the rate of mortality from COPD, identifying other factors that may influence mortality and are amenable to interventions in individuals with COPD is of substantial interest.

Studies, mostly cross-sectional ones, have related nutritional factors including the intake of fruits and vegetables, which are rich sources of antioxidants, to pulmonary function and $\mathrm{COPD}^{(4-14)}$. Dietary intakes of vitamin $\mathrm{C}^{(15-19)}$, vitamin $\mathrm{E}^{(20,21)}, \quad \beta$-carotene $\mathrm{e}^{(18,19,22)}$ and carotenoids ${ }^{(21)}$ have been linked to lung function. Furthermore, circulating concentrations of antioxidants including carotenoids, vitamin C, vitamin $\mathrm{E}$ and vitamin $\mathrm{A}$ have been linked to pulmonary function in cross-sectional studies ${ }^{(23-31)}$ and to change in pulmonary function in prospective studies ${ }^{(32-34)}$.

Assuming that adequate nutritional status may help to preserve lung function and that preserved lung function reduces mortality, adequate nutritional status might reduce mortality among people with impaired lung function. An ecological study has suggested that increased intakes of fruits and fish are inversely correlated with COPD mortality $^{(35)}$. Prospective studies have found that the intakes of fruits and vitamin E are inversely associated with mortality from $\mathrm{COPD}^{(36)}$. Yet, little is known about the associations between antioxidant concentrations and mortality in adults with obstructive lung function. Oxidation is considered to be a key factor in the pathogenesis of $\operatorname{COPD}^{(37-39)}$, but very little is known about the role of oxidation in and any possible beneficial effects of antioxidants on the prognosis

Abbreviations: COPD, chronic obstructive pulmonary disease; FEV1, forced expiratory volume in $1 \mathrm{~s}$; FVC, forced vital capacity; NHANES III, Third National Health and Nutrition Examination Survey.

*Corresponding author: E. S. Ford, fax +1770488 5965, email eford@cdc.gov 
of this disease. Therefore, the objective of the present study was to examine the associations between circulating concentrations of carotenoids ( $\alpha$-carotene, $\beta$-carotene, cryptoxanthin, lutein/zeaxanthin, and lycopene), vitamin $\mathrm{C}$, vitamin $\mathrm{E}$, and Se and all-cause mortality in a cohort of US adults with obstructive lung function.

\section{Methods}

The present study is based on data obtained from the Third National Health and Nutrition Examination Survey (NHANES III) Linked Mortality Study (baseline examination from 1988 to 1994; mortality follow-up through 2006$)^{(40,41)}$. A complex sampling design (stratified multistage probability design) was used to select participants, who constituted a representative sample of the civilian non-institutionalised population in the USA. The participants were interviewed at their homes and extended an invitation to undergo an examination in the mobile examination centre, where they completed additional questionnaires, underwent a series of examinations, and provided blood and urine samples. The interview and examination response rates were 86 and $78 \%$, respectively. NHANES III received approval from the Institutional Review Board.

A probabilistic match of participants' information with the National Death Index death certificate records was conducted to identify deceased participants. If a match was not made, the participant was assumed to be alive at the end of the followup period. International Classification of Diseases-10 codes I00-I99 and C00-C97 were used to define deaths from circulatory disease and cancer, respectively.

Adults were eligible for a pulmonary function test without post-bronchodilator testing. The procedures used to conduct spirometry have been detailed elsewhere ${ }^{(42)}$. The following equations were used to calculate predicted forced expiratory volume in $1 \mathrm{~s}$ (FEV1) and forced vital capacity (FVC) in adults:

\section{FEV1:}

White men: $0.5536-0.01303 \times$ age $-0.000172 \times$ age $^{2}$ $+0.00014098 \times$ height $^{2}$,

African American men: $0.3411-0.02309 \times$ age

$$
+0.00013194 \times \text { height }^{2}
$$

Mexican American men: $0.6306-0.02928 \times$ age

$$
+0.00015104 \times \text { height }^{2},
$$

White women: $0.4333-0.00361 \times$ age $-0.000194 \times$ age $^{2}$

$$
+0.00011496 \times \text { height }^{2} \text {, }
$$

African American women: $0.3433-0.01283 \times$ age

$$
\begin{aligned}
& -0.000097 \times \text { age }^{2} \\
& +0.00010846 \times \text { height }^{2}
\end{aligned}
$$

Mexican American women: $0.4529-0.01178 \times$ age

$$
\begin{aligned}
& -0.000113 \times \text { age }^{2} \\
& +0.00012154 \times \text { height }^{2} .
\end{aligned}
$$

FVC:

White men: $-0.1933+0.00064 \times$ age $-0.000269 \times$ age $^{2}$

$$
+0.00018642 \times \text { height }^{2}
$$

African American men: - $0.1517-0.01821 \times$ age

$$
+0.00016643 \times \text { height }^{2} \text {, }
$$

Mexican American men: $0.2376-0.00891 \times$ age

$$
-0.000182 \times \text { age }^{2}+0.00017823
$$$$
\times \text { height }^{2} \text {, }
$$

White women: $-0.3560+0.01870 \times$ age -0.000382

$$
\times \text { age }^{2}+0.00014815 \times \text { height }^{2},
$$

African American women: $-0.3039+0.00536 \times$ age

$$
\begin{aligned}
& -0.000265 \times \text { age }^{2} \\
& +0.00013606 \times \text { height }^{2},
\end{aligned}
$$

Mexican American women: $0.1210+0.00307 \times$ age

$$
\begin{aligned}
& -0.000237 \times \text { age }^{2} \\
& +0.00014246 \times \text { height }^{2} .
\end{aligned}
$$

Mild obstructive impairment was defined as a FEV1/FVC $<0.70$ and a FEV1 $\geq 80 \%$, moderate obstructive impairment was defined as a FEV1/FVC $<0.70$ and a FEV1 50 to $<80 \%$ predicted, and severe obstructive impairment was defined as a FEV1/FVC $<0.70$ and a FEV1 $<50 \%$ predicted. Participants with mild, moderate or severe COPD were combined for analyses that examined associations between antioxidant concentrations and mortality risk.

The serum concentrations of five carotenoids ( $\alpha$-carotene, $\beta$-carotene, $\beta$-cryptoxanthin, lutein/zeaxanthin, and lycopene), vitamin $C$ and $\alpha$-tocopherol were measured using an isocratic reversed-phase HPLC. The serum concentrations of Se were measured using graphite furnace atomic absorption spectroscopy.

The following covariates were included in the analyses: age; sex; self-reported race or ethnicity (white, African American and other); educational level $(<12,12$, or $>12$ years); smoking status; alcohol consumption; leisure-time physical activity; use of vitamin or mineral supplements; systolic blood pressure; HDL-cholesterol; non-HDL-cholesterol; BMI; C-reactive protein; urinary albumin:creatinine ratio; health status; histories of myocardial infarction and stroke; diabetes. Sociodemographic and lifestyle variables were included in the analyses because these variables are generally strongly associated with mortality. Furthermore, these variables are also associated with antioxidant concentrations. Lipid concentrations were included in the analyses because many of the antioxidants are lipid soluble. C-reactive protein as a marker of inflammation was included in the analyses because sources of inflammation can reduce antioxidant concentrations. Systolic blood pressure, BMI, urinary albumin:creatinine ratio, health status, diabetes, and histories of myocardial infarction and stroke were included in the analyses because these risk factors and conditions predict mortality and are associated with antioxidant concentrations.

Participants who reported that they had smoked at least 100 cigarettes during their lifetime and that they still smoke were designated as current smokers. Participants who reported 
that they had smoked at least 100 cigarettes during their lifetime and that they no longer smoke were designated as former smokers. Participants reporting not having smoked at least 100 cigarettes were designated as never smokers. Using information from a FFQ, the frequency of alcohol consumption per month was estimated. Participants who engaged three or more times per week in an activity with a metabolic equivalent level $\geq 6$ (for those aged $\geq 60$ years) and with a metabolic equivalent $\geq 7$ (for those aged $<60$ years) were considered to be vigorously active, participants who engaged five or more times per week in activities of which no more than two could be considered vigorous were considered to be moderately active, participants who engaged in activities that were not vigorous or moderate were considered to be lightly active, and participants who engaged in no leisuretime physical activity were considered to sedentary. Use of any vitamins or minerals by the participants was determined from the responses provided to the question 'Have you taken any vitamins or minerals in the past month?'

The second and third systolic blood pressure measurements were averaged. BMI $\left(\mathrm{kg} / \mathrm{m}^{2}\right)$ was calculated from the measured weight and height. The concentrations of HDL-cholesterol were measured on a Hitachi 704 analyser (Boehringer Mannheim Diagnostics) after precipitation of other lipoproteins with a heparin-manganese chloride mixture. The concentrations of non-HDL-cholesterol were calculated by subtracting the concentration of HDL-cholesterol from that of total cholesterol. The serum concentrations of C-reactive protein were measured using latex-enhanced nephelometry on the Behring Nephelometer Analyzer System (Behring Diagnostics, Inc.). The urinary concentrations of albumin were measured using a fluorescent immunoassay on a Sequoia-Turner fluorometer

Table 1. Age-adjusted baseline means and percentages of study variables among adults aged 20-79 years with obstructive lung function, by mortality status, National Health and Nutrition Examination Survey III (1988-94)

(Mean values or percentages with their standard errors)

\begin{tabular}{|c|c|c|c|c|c|c|c|}
\hline & & & \multicolumn{4}{|c|}{ Mortality status } & \multirow[b]{3}{*}{$P$} \\
\hline & \multicolumn{2}{|c|}{ Total ( $n$ 1492) } & \multicolumn{2}{|c|}{ Dead ( $n$ 629) } & \multicolumn{2}{|c|}{ Alive $(n 863)$} & \\
\hline & Mean & SE & Mean & SE & Mean & SE & \\
\hline Age (years) & $55 \cdot 7$ & 0.7 & $65 \cdot 8$ & 0.7 & $50 \cdot 5$ & 0.8 & $<0.001$ \\
\hline Education (years) & $12 \cdot 3$ & 0.2 & $11 \cdot 0$ & 0.3 & $12 \cdot 5$ & 0.2 & $<0.001$ \\
\hline No. of drinks (per month) & $10 \cdot 4$ & 0.8 & 9.9 & $2 \cdot 1$ & $10 \cdot 4$ & 0.9 & 0.818 \\
\hline Systolic blood pressure $(\mathrm{mmHg})$ & 121.4 & 0.6 & $124 \cdot 5$ & $1 \cdot 3$ & $120 \cdot 3$ & 0.7 & 0.005 \\
\hline HDL-cholesterol $(\mathrm{mmol} / \mathrm{l})$ & 1.3 & 0.0 & $1 \cdot 1$ & 0.1 & $1 \cdot 3$ & 0.0 & 0.015 \\
\hline Non-HDL-cholesterol (mmol/l) & $4 \cdot 1$ & 0.1 & $4 \cdot 2$ & 0.1 & $4 \cdot 1$ & 0.0 & 0.291 \\
\hline BMI $\left(\mathrm{kg} / \mathrm{m}^{2}\right)$ & $26 \cdot 5$ & 0.3 & $27 \cdot 6$ & 0.9 & $26 \cdot 5$ & 0.3 & 0.227 \\
\hline Albumin:creatinine ratio $(\mathrm{mg} / \mathrm{g})$ & $17 \cdot 8$ & 1.4 & $22 \cdot 3$ & 3.4 & $14 \cdot 0$ & 1.0 & 0.021 \\
\hline$\alpha$-Carotene $(\mu \mathrm{mol} / \mathrm{l})$ & 0.08 & 0.00 & 0.06 & 0.01 & 0.09 & 0.00 & $<0.001$ \\
\hline$\beta$-Carotene $(\mu \mathrm{mol} / \mathrm{l})$ & 0.34 & 0.01 & 0.26 & 0.01 & 0.35 & 0.01 & $<0.001$ \\
\hline Cryptoxanthin $(\mu \mathrm{mol} / \mathrm{l})$ & 0.15 & 0.00 & 0.11 & 0.01 & $0 \cdot 16$ & 0.01 & $<0.001$ \\
\hline Lutein/zeaxanthin $(\mu \mathrm{mol} / \mathrm{l})$ & 0.37 & 0.01 & 0.33 & 0.02 & 0.37 & 0.01 & 0.015 \\
\hline Lycopene $(\mu \mathrm{mol} / \mathrm{l})$ & 0.45 & 0.01 & 0.41 & 0.03 & 0.46 & 0.01 & 0.120 \\
\hline Total carotenoids $(\mu \mathrm{mol} / \mathrm{l})$ & 1.38 & 0.03 & $1 \cdot 17$ & 0.06 & 1.42 & 0.03 & $<0.001$ \\
\hline Se $(\mathrm{nmol} / \mathrm{l})$ & 1.61 & 0.02 & 1.60 & 0.03 & 1.62 & 0.02 & 0.581 \\
\hline Vitamin C (mmol/l) & 39.4 & $1 \cdot 8$ & 33.8 & 4.0 & $40 \cdot 9$ & 1.9 & 0.103 \\
\hline Vitamin $E(\mu \mathrm{mol} / \mathrm{l})$ & $27 \cdot 0$ & 0.6 & $27 \cdot 1$ & 1.4 & $27 \cdot 0$ & $0 \cdot 6$ & 0.977 \\
\hline FEV1 (litres) & $2 \cdot 8$ & 0.0 & $2 \cdot 7$ & 0.1 & $2 \cdot 9$ & 0.0 & 0.291 \\
\hline FVC (litres) & 4.4 & 0.0 & 4.4 & 0.1 & 4.4 & 0.1 & 0.848 \\
\hline FEV1 (\% predicted) & $79 \cdot 8$ & 0.7 & $75 \cdot 9$ & $2 \cdot 6$ & $81 \cdot 5$ & 0.7 & 0.040 \\
\hline FVC (\% predicted) & $98 \cdot 9$ & 0.7 & $96 \cdot 8$ & $2 \cdot 4$ & $100 \cdot 2$ & 0.7 & 0.206 \\
\hline Men (\%) & $59 \cdot 8$ & $1 \cdot 8$ & $80 \cdot 5$ & $2 \cdot 3$ & $56 \cdot 8$ & 1.9 & $<0.001$ \\
\hline \multicolumn{8}{|l|}{ Race or ethnicity } \\
\hline White (\%) & 83.5 & $1 \cdot 8$ & $80 \cdot 8$ & $5 \cdot 3$ & 83.9 & $1 \cdot 8$ & 0.569 \\
\hline African American (\%) & 7.5 & 0.9 & $16 \cdot 1$ & $5 \cdot 0$ & $6 \cdot 8$ & 0.9 & 0.070 \\
\hline Mexican American (\%) & $2 \cdot 2$ & 0.4 & 1.4 & 0.7 & $2 \cdot 2$ & 0.4 & 0.247 \\
\hline Other (\%) & $6 \cdot 8$ & 1.5 & $1 \cdot 7$ & $1 \cdot 0$ & $7 \cdot 1$ & $1 \cdot 6$ & 0.007 \\
\hline High-school graduate or higher (\%) & $74 \cdot 0$ & $2 \cdot 6$ & $45 \cdot 0$ & $4 \cdot 2$ & $77 \cdot 1$ & $2 \cdot 9$ & $<0.001$ \\
\hline \multicolumn{8}{|l|}{ Smoking status } \\
\hline Current smoker (\%) & $44 \cdot 8$ & $2 \cdot 5$ & $59 \cdot 7$ & $7 \cdot 3$ & $41 \cdot 0$ & $2 \cdot 7$ & 0.028 \\
\hline Former smoker (\%) & $27 \cdot 0$ & 1.9 & $13 \cdot 4$ & $1 \cdot 3$ & 28.5 & $2 \cdot 2$ & $<0.001$ \\
\hline Never smoker (\%) & $28 \cdot 2$ & $2 \cdot 5$ & $26 \cdot 9$ & 7.5 & $30 \cdot 5$ & $2 \cdot 8$ & 0.676 \\
\hline Moderate-vigorous leisure-time physical activity (\%) & $45 \cdot 0$ & $2 \cdot 4$ & 39.8 & $7 \cdot 8$ & $46 \cdot 4$ & $2 \cdot 9$ & 0.429 \\
\hline Vitamin or mineral supplement use during past $30 \mathrm{~d}(\%)$ & $40 \cdot 3$ & $2 \cdot 2$ & $35 \cdot 2$ & 7.5 & $41 \cdot 8$ & $2 \cdot 3$ & 0.397 \\
\hline C-reactive protein > $3 \mathrm{mg} / \mathrm{l}(\%)$ & 29.5 & $2 \cdot 1$ & $36 \cdot 2$ & $5 \cdot 7$ & $28 \cdot 3$ & $2 \cdot 6$ & 0.249 \\
\hline$\geq$ Good health status (\%) & $84 \cdot 6$ & $2 \cdot 4$ & $74 \cdot 1$ & $6 \cdot 8$ & $87 \cdot 2$ & $2 \cdot 0$ & 0.029 \\
\hline Diabetes (\%) & $5 \cdot 3$ & 0.7 & $5 \cdot 6$ & 0.8 & $4 \cdot 2$ & 0.8 & 0.212 \\
\hline History of myocardial infarction (\%) & $3 \cdot 8$ & 0.7 & 4.9 & 1.5 & $2 \cdot 7$ & 0.7 & 0.196 \\
\hline History of stroke (\%) & $1 \cdot 7$ & 0.4 & 3.0 & 1.5 & $1 \cdot 2$ & 0.4 & 0.230 \\
\hline
\end{tabular}

FEV1, forced expiratory volume in $1 \mathrm{~s}$; FVC, forced vital capacity. 
(Sequoia-Turner Corporation). The urinary concentrations of creatinine were measured from the rate of colour formation on a Beckman Synchron AS/ASTRA clinical analyser (Beckman Instruments, Inc.).

Participants with a history of myocardial infarction or stroke were identified from the responses provided to the questions 'Has a doctor ever told you that you had a heart attack?' and 'Has a doctor ever told you that you had a stroke?', respectively. Participants who provided a positive response to the question 'Have you ever been told by a doctor that you have diabetes or sugar diabetes?' or had glycated $\mathrm{Hb}$ concentration $\geq 6.5 \%$ were considered to have diabetes.

Men and non-pregnant women aged 20-79 years who underwent a spirometric examination in the mobile examination centre and had reproducible FEV1 and FVC results were included in the analyses. Using the direct method, age adjustment was done to the projected year 2000 US population for adults aged 20-79 years. Least-squares adjusted mean concentrations of antioxidants were calculated. Proportionalhazards analysis was used to estimate hazard ratios for antioxidants and mortality. In these multivariable models, antioxidants were modelled as continuous variables and again as quintiles calculated from the distributions of antioxidants among participants with obstructive lung function. To better approximate a normal distribution of several antioxidants, the following transformations were used in regression analyses: log transformation for $\beta$-carotene, lutein/zeaxanthin, lycopene, total carotenoids, and vitamin $\mathrm{E}$ and square root transformation for vitamin C. SAS (SAS Institute Inc.) and SUDAAN (Research Triangle Institute) were used to conduct statistical analyses.

\section{Results}

Of the 15033 men and non-pregnant women aged 20-79 years who visited the mobile examination centre, $14082 \mathrm{had}$ reproducible FEV1 and FVC results. After exclusion of participants with an unreliable examination result, 13134 remained. Of these participants, 1746 had obstructive lung function and 12168-12516 participants had a measurement of the antioxidants. After exclusion of participants with missing study variables, the analytical sample size was reduced to 1492 participants with obstructive lung function.

The 1492 participants with obstructive lung function included 907 men, 585 women, 903 whites, 315 African Americans, 232 Mexican Americans, and forty-two participants of another race or ethnicity. The mean and median ages were 55.7 and 58.0 years, respectively.

Among adults with obstructive lung function, 629 had died. The mean and median follow-up periods were 12.9 and 14.0 years, respectively. Differences in the means and percentages of study variables between participants who died and those who remained alive among adults with obstructive lung function are given in Table 1. Decedents had lower age-adjusted mean concentrations of $\alpha$-carotene, $\beta$-carotene, cryptoxanthin, lutein/zeaxanthin, and total carotenoids than survivors.

In age-adjusted regression models, the concentrations of all antioxidants, except Se, modelled as continuous variables
Table 2. Associations between antioxidant concentrations and allcause mortality among US adults aged $20-79$ years with obstructive lung function, National Health and Nutrition Examination Survey III Linked Mortality File 1988-94 to 2006

(Hazard ratios and $95 \%$ confidence intervals)

\begin{tabular}{|c|c|c|c|}
\hline Antioxidants* & Hazard ratio & $95 \% \mathrm{Cl}$ & $P$ \\
\hline \multicolumn{4}{|l|}{ Model $1 \dagger$} \\
\hline$\alpha$-Carotene $(\mu \mathrm{mol} / \mathrm{l})$ & 0.04 & $0.00,0.33$ & 0.004 \\
\hline$\beta$-Carotene $(\mu \mathrm{mol} / \mathrm{l})$ & 0.76 & $0.66,0.88$ & $<0.001$ \\
\hline Cryptoxanthin $(\mu \mathrm{mol} / \mathrm{l})$ & $0 \cdot 10$ & $0.02,0.46$ & 0.004 \\
\hline Lutein/zeaxanthin $(\mu \mathrm{mol} / \mathrm{l})$ & 0.68 & $0.55,0.85$ & 0.001 \\
\hline Lycopene $(\mu \mathrm{mol} / \mathrm{l})$ & 0.71 & $0.61,0.81$ & $<0.001$ \\
\hline Total carotenoids $(\mu \mathrm{mol} / \mathrm{l})$ & 0.59 & $0.48,0.73$ & $<0.001$ \\
\hline $\mathrm{Se}(\mathrm{nmol} / \mathrm{l})$ & 0.77 & $0.41,1.46$ & 0.416 \\
\hline Vitamin C (mmol/l) & $0 \cdot 88$ & $0.84,0.92$ & $<0.001$ \\
\hline Vitamin $E(\mu \mathrm{mol} / \mathrm{l})$ & 0.71 & $0.52,0.98$ & 0.039 \\
\hline \multicolumn{4}{|l|}{ Model $2 \ddagger$} \\
\hline$\alpha$-Carotene $(\mu \mathrm{mol} / \mathrm{l})$ & 0.12 & $0.02,0.88$ & 0.037 \\
\hline$\beta$-Carotene $(\mu \mathrm{mol} / \mathrm{l})$ & 0.83 & $0.70,0.97$ & 0.022 \\
\hline Cryptoxanthin $(\mu \mathrm{mol} / \mathrm{l})$ & $0 \cdot 18$ & $0.04,0.77$ & 0.022 \\
\hline Lutein/zeaxanthin $(\mu \mathrm{mol} / \mathrm{l})$ & 0.71 & $0.57,0.89$ & 0.004 \\
\hline Lycopene $(\mu \mathrm{mol} / \mathrm{l})$ & 0.75 & $0.64,0.87$ & $<0.001$ \\
\hline Total carotenoids $(\mu \mathrm{mol} / \mathrm{l})$ & 0.65 & $0.51,0.82$ & 0.001 \\
\hline $\mathrm{Se}(\mathrm{nmol} / \mathrm{l})$ & 0.83 & $0.44,1.58$ & 0.568 \\
\hline Vitamin C (mmol/l) & 0.91 & $0.87,0.95$ & $<0.001$ \\
\hline Vitamin E $(\mu \mathrm{mol} / \mathrm{l})$ & 0.88 & $0.66,1.19$ & 0.412 \\
\hline \multicolumn{4}{|l|}{ Model $3 \S$} \\
\hline$\alpha$-Carotene $(\mu \mathrm{mol} / \mathrm{l})$ & 0.52 & $0.08,3.56$ & 0.499 \\
\hline$\beta$-Carotene $(\mu \mathrm{mol} / \mathrm{l})$ & 0.88 & $0.74,1.04$ & 0.133 \\
\hline Cryptoxanthin $(\mu \mathrm{mol} / \mathrm{l})$ & 0.36 & $0.10,1.35$ & 0.127 \\
\hline Lutein/zeaxanthin $(\mu \mathrm{mol} / \mathrm{l})$ & 0.80 & $0.64,1.00$ & 0.052 \\
\hline Lycopene $(\mu \mathrm{mol} / \mathrm{l})$ & 0.78 & $0.67,0.91$ & 0.002 \\
\hline Total carotenoids $(\mu \mathrm{mol} / \mathrm{l})$ & 0.74 & $0.58,0.94$ & 0.017 \\
\hline $\mathrm{Se}(\mathrm{nmol} / \mathrm{l})$ & 1.00 & $0.55,1.81$ & 1.000 \\
\hline Vitamin $\mathrm{C}(\mathrm{mmol} / \mathrm{l})$ & 0.94 & $0.90,0.99$ & 0.021 \\
\hline Vitamin $E(\mu \mathrm{mol} / /)$ & 0.98 & $0.73,1.32$ & 0.884 \\
\hline \multicolumn{4}{|l|}{ Model 4\| } \\
\hline$\alpha$-Carotene $(\mu \mathrm{mol} / \mathrm{l})$ & 0.55 & $0.07,4.34$ & 0.566 \\
\hline$\beta$-Carotene $(\mu \mathrm{mol} / \mathrm{l})$ & 0.89 & $0.75,1.07$ & 0.210 \\
\hline Cryptoxanthin $(\mu \mathrm{mol} / \mathrm{l})$ & 0.42 & $0.12,1.53$ & 0.184 \\
\hline Lutein/zeaxanthin $(\mu \mathrm{mol} / \mathrm{l})$ & $0 \cdot 81$ & $0.62,1.05$ & 0.111 \\
\hline Lycopene $(\mu \mathrm{mol} / \mathrm{l})$ & $0 \cdot 80$ & $0.69,0.94$ & 0.007 \\
\hline Total carotenoids $(\mu \mathrm{mol} / \mathrm{l})$ & 0.75 & $0.57,1.00$ & 0.051 \\
\hline $\mathrm{Se}(\mathrm{nmol} / \mathrm{l})$ & 0.97 & $0.55,1.74$ & 0.930 \\
\hline Vitamin C (mmol/l) & 0.95 & $0.91,1.00$ & 0.042 \\
\hline Vitamin $E(\mu \mathrm{mol} / /)$ & 1.00 & $0.67,1.49$ & 0.989 \\
\hline \multicolumn{4}{|l|}{ Model 59 } \\
\hline$\alpha$-Carotene $(\mu \mathrm{mol} / \mathrm{l})$ & 0.62 & $0.08,5.06$ & 0.653 \\
\hline$\beta$-Carotene $(\mu \mathrm{mol} / \mathrm{l})$ & 0.92 & $0.78,1.09$ & 0.309 \\
\hline Cryptoxanthin $(\mu \mathrm{mol} / \mathrm{l})$ & 0.42 & $0.13,1.39$ & 0.151 \\
\hline Lutein/zeaxanthin $(\mu \mathrm{mol} / \mathrm{l})$ & 0.86 & $0.66,1.11$ & 0.235 \\
\hline Lycopene $(\mu \mathrm{mol} / \mathrm{l})$ & $0 \cdot 80$ & $0.67,0.95$ & 0.013 \\
\hline Total carotenoids $(\mu \mathrm{mol} / \mathrm{l})$ & 0.78 & $0.59,1.03$ & 0.075 \\
\hline $\mathrm{Se}(\mathrm{nmol} / \mathrm{l})$ & 0.96 & $0.52,1.79$ & 0.900 \\
\hline Vitamin $C(\mathrm{mmol} / \mathrm{l})$ & 0.95 & $0.91,1.00$ & 0.046 \\
\hline Vitamin $E(\mu \mathrm{mol} / /)$ & 1.02 & $0.69,1.50$ & 0.922 \\
\hline
\end{tabular}

* Estimates for each antioxidant were not adjusted for the concentrations of other antioxidants.

† Adjusted for age.

$\ddagger$ Adjusted for variables in model 1 plus sex, race or ethnicity, and education.

$\S$ Adjusted for variables in model 2 plus smoking status, alcohol consumption, leisure-time physical activity, and use of vitamin or mineral supplements.

\|Adjusted for variables in model 3 plus systolic blood pressure, HDL-cholesterol, non-HDL-cholesterol, BMI, C-reactive protein and albumin:creatinine ratio.

I Adjusted for variables in model 4 plus health status, diabetes, history of myocardial infarction, and history of stroke.

were inversely associated with all-cause mortality (Table 2). With progressive increasing levels of adjustment, the statistical significance of the hazard ratios for most antioxidants dwindled until only the concentrations of lycopene 
Table 3. Associations between antioxidant concentrations and causespecific mortality among US adults aged 20-79 years with obstructive lung function, National Health and Nutrition Examination Survey III Linked Mortality File $1988-94$ to $2006^{*}$

(Adjusted hazard ratios and $95 \%$ confidence intervals)

\begin{tabular}{|c|c|c|c|}
\hline Antioxidants & Hazard ratio & $95 \% \mathrm{Cl}$ & $P$ \\
\hline \multicolumn{4}{|l|}{$\begin{array}{l}\text { Circulatory disease deaths } \\
\text { (225 deaths) }\end{array}$} \\
\hline$\alpha$-Carotene $(\mu \mathrm{mol} / \mathrm{l})$ & $4 \cdot 10$ & $0 \cdot 37,45 \cdot 19$ & 0.243 \\
\hline$\beta$-Carotene $(\mu \mathrm{mol} / \mathrm{l})$ & $1 \cdot 16$ & $0.90,1.51$ & 0.245 \\
\hline Cryptoxanthin $(\mu \mathrm{mol} / \mathrm{l})$ & $1 \cdot 12$ & $0.38,3.31$ & 0.829 \\
\hline Lutein/zeaxanthin $(\mu \mathrm{mol} / \mathrm{l})$ & 1.04 & $0.72,1.49$ & 0.828 \\
\hline Lycopene $(\mu \mathrm{mol} / \mathrm{l})$ & 0.92 & $0.68,1.23$ & 0.560 \\
\hline Total carotenoids $(\mu \mathrm{mol} / \mathrm{l})$ & $1 \cdot 11$ & $0.74,1.65$ & 0.604 \\
\hline $\mathrm{Se}(\mathrm{nmol} / \mathrm{l})$ & 1.04 & $0.32,3.32$ & 0.952 \\
\hline Vitamin $\mathrm{C}(\mathrm{mmol} / \mathrm{l})$ & 1.04 & $0.94,1.16$ & 0.448 \\
\hline Vitamin $E(\mu \mathrm{mol} / /)$ & 1.14 & $0.62,2.08$ & 0.664 \\
\hline \multicolumn{4}{|l|}{ Cancer deaths (204 deaths) } \\
\hline$\alpha$-Carotene $(\mu \mathrm{mol} / \mathrm{l})$ & 0.76 & $0.01,41 \cdot 30$ & 0.889 \\
\hline$\beta$-Carotene $(\mu \mathrm{mol} / \mathrm{l})$ & 0.90 & $0.70,1.17$ & 0.433 \\
\hline Cryptoxanthin $(\mu \mathrm{mol} / \mathrm{l})$ & 0.20 & $0.01,4.52$ & 0.303 \\
\hline Lutein/zeaxanthin $(\mu \mathrm{mol} / \mathrm{l})$ & 0.88 & $0.57,1.36$ & 0.560 \\
\hline Lycopene $(\mu \mathrm{mol} / \mathrm{l})$ & 0.83 & $0.63,1.09$ & 0.176 \\
\hline Total carotenoids $(\mu \mathrm{mol} / \mathrm{l})$ & 0.77 & $0.51,1.17$ & 0.221 \\
\hline $\mathrm{Se}(\mathrm{nmol} / \mathrm{l})$ & 0.93 & $0.41,2.12$ & 0.868 \\
\hline Vitamin $C(\mathrm{mmol} / \mathrm{l})$ & 0.85 & $0.78,0.91$ & $<0.001$ \\
\hline Vitamin $E(\mu \mathrm{mol} / \mathrm{l})$ & 0.64 & $0.22,1.88$ & 0.412 \\
\hline \multicolumn{4}{|l|}{ Other deaths (200 deaths) } \\
\hline$\alpha$-Carotene $(\mu \mathrm{mol} / \mathrm{l})$ & 0.06 & $0.00,1.98$ & 0.113 \\
\hline$\beta$-Carotene $(\mu \mathrm{mol} / \mathrm{l})$ & 0.76 & $0.58,1.01$ & 0.055 \\
\hline Cryptoxanthin $(\mu \mathrm{mol} / \mathrm{l})$ & 0.19 & $0.02,1.51$ & 0.113 \\
\hline Lutein/zeaxanthin $(\mu \mathrm{mol} / \mathrm{l})$ & 0.70 & $0.41,1.17$ & 0.171 \\
\hline Lycopene $(\mu \mathrm{mol} / \mathrm{l})$ & 0.70 & $0.51,0.95$ & 0.024 \\
\hline Total carotenoids $(\mu \mathrm{mol} / \mathrm{l})$ & 0.58 & $0.36,0.93$ & 0.024 \\
\hline Se $(\mathrm{nmol} / \mathrm{l})$ & 0.85 & $0.28,2.58$ & 0.775 \\
\hline Vitamin C $(\mathrm{mmol} / \mathrm{l})$ & 0.99 & $0.90,1.10$ & 0.919 \\
\hline Vitamin $E(\mu \mathrm{mol} / \mathrm{l})$ & 1.39 & $0.60,3.23$ & 0.435 \\
\hline
\end{tabular}

* Log transformations for the concentrations of $\beta$-carotene, lutein/zeaxanthin lycopene, total carotenoids and vitamin E. Square root transformation for the concentration of vitamin C. Adjusted for age, sex, race or ethnicity, education, smoking status, alcohol consumption, leisure-time physical activity, use of vitamin or mineral supplements, systolic blood pressure, HDL-cholesterol, non-HDL-cholesterol, BMI, C-reactive protein, albumin:creatinine ratio, health status, diabetes, history of myocardial infarction and history of stroke. Estimates for each antioxidant were not adjusted for the concentrations of other antioxidants.

$(P=0 \cdot 013)$ and vitamin $\mathrm{C}(P=0.046)$ remained significantly and inversely associated with all-cause mortality in the maximally adjusted model (Table 2).

The concentrations of none of the antioxidants were significantly associated with mortality from circulatory diseases (Table 3). However, the concentrations of vitamin $\mathrm{C}$ were inversely associated with mortality from cancer. In addition, the concentrations of lutein/zeaxanthin and lycopene were inversely associated with mortality from causes other than circulatory disease and cancer.

To examine the possibility of nonlinearity in the associations between antioxidant concentrations and all-cause mortality, a term for the squared concentrations of antioxidants was added to the proportional-hazards models, which proved to be statistically significant for lutein/zeaxanthin, total carotenoids, Se, vitamin C and vitamin E. Adjusted hazard ratios by quintiles of antioxidant concentrations are given in Table 4.
The associations between antioxidant concentrations and mortality did not vary by sex $\left(P_{\text {interactions }}>0.050\right)$. When possible interactions by race or ethnicity were examined, only the interaction term for lycopene was found to be statistically significant (Table 5). Except for $\beta$-carotene, the adjusted mean concentrations of antioxidants varied by race or ethnicity.

Detection for the presence of two-way interactions between antioxidant concentrations modelled as continuous variables and all-cause mortality was done. Significant interactions were found between the concentrations of vitamin $\mathrm{E}$ and those of $\beta$-carotene, cryptoxanthin, and lutein/zeaxanthin. Furthermore, significant interactions were found between the concentrations of lutein/zeaxanthin and those of cryptoxanthin and lycopene. When the concentration of each of the antioxidants was dichotomised using the median concentration and a four-level variable for each pair of antioxidants was created, none of the four-level variables was found to be a statistically significant predictor of mortality and, thus, shed little light on the interactions.

In general, antioxidant concentrations were lowest in participants who were current smokers and highest in participants who had never smoked (Table 6). Only the association between log-transformed lutein/zeaxanthin concentrations and all-cause mortality varied by smoking status $\left(P_{\text {interaction }}\right.$ for continuous variable $=0 \cdot 048)$. The maximally adjusted hazard ratios for continuous log-transformed concentrations were $0.62(95 \%$ CI $0.46,0.83)$ for current smokers, 1.03 (95\% CI $0.71,1.48)$ for former smokers, and 1.54 (95\% CI $0.78,3.04$ ) for never smokers (Table 6). The concentrations of lutein/zeaxanthin, lycopene and total carotenoids were inversely associated with all-cause mortality in current smokers.

\section{Discussion}

Oxidation is a critical factor in the pathogenesis and pathophysiology of $\mathrm{COPD}^{(37-39)}$. Although less clear, ongoing oxidative stress may exert a deleterious effect on the prognosis of those afflicted with this condition. If so, adequate antioxidant defences might be especially important for the welfare of people with COPD. The results of the present study showing that the concentrations of vitamin $\mathrm{C}$ and lycopene are inversely associated with all-cause mortality in the study cohort with obstructive lung function provide measured support for this contention.

If the results of the present study do not represent chance findings, a couple of alternate explanations deserve consideration. First, vitamin $\mathrm{C}$ and lycopene may have in fact exerted beneficial effects in adults with obstructive lung function. Second, vitamin $\mathrm{C}$ and lycopene may represent risk markers for other factors that are responsible for the observed associations between the two antioxidants and mortality. Because fruits and vegetables are rich sources of both substances, one or more of the other compounds in fruits and vegetables may have been responsible for the observed associations. Along the same lines, antioxidants may represent markers for certain lifestyle characteristics that favourably affect mortality. 


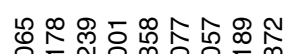

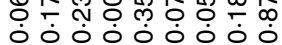

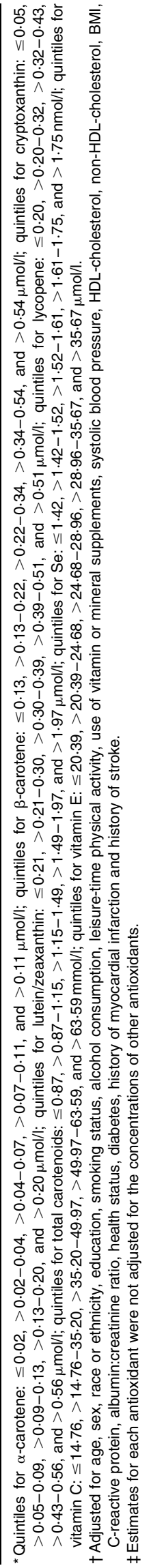

Prospective studies have reported that carotenoid concentrations are inversely associated with mortality ${ }^{(43-67)}$, but not all studies have done so ${ }^{(52,68-70)}$. These studies are supported by prospective studies of dietary or supplemental intakes of carotenoids $^{(64,71-74)}$, although other studies have failed to observe significant associations between antioxidant intake and mortality ${ }^{(70,75-78)}$. Furthermore, in randomised trials of $\beta$-carotene, mortality was found to increase in the experimental group $^{(77,79)}$. However, we were unable to find studies that have examined whether antioxidant concentrations predict mortality in adults with obstructive lung function. Therefore, the results of the present study present novel information.

Evidence regarding the association between circulating concentrations of lycopene and mortality is mixed, with several studies providing supportive evidence ${ }^{(57,58,60,65)}$ and others failing to do $s \mathrm{O}^{(49,67,80)}$. If lycopene reduces mortality, it is possible that COPD adults with higher lycopene concentrations would experience beneficial effects similar to those experienced by the population at large. The literature pertaining to the health effects of lycopene has zeroed in mostly on cancer ${ }^{(81)}$. Of the carotenoids, the concentrations of lycopene had the strongest association with lung cancer $^{(82)}$, a condition to which adults with COPD are particularly susceptible given their smoking history. It is possible that lycopene may exert a favourable effect on all-cause mortality by reducing the risk of lung cancer. Adults with COPD are at an increased risk of mortality from $\mathrm{CVD}^{(83)}$. Research has suggested that the intake and circulating concentrations of lycopene may be inversely associated with $\mathrm{CVD}^{(84-86)}$. Besides being a strong singlet oxygen quencher ${ }^{(87)}$, lycopene has been shown to affect endothelial function ${ }^{(88,89)}$, HDL function $^{(90)}$, and matrix metalloproteinase-9 induction ${ }^{(91)}$.

Whether the beneficial effects of adequate lycopene status specific to adults with COPD exist is less clear. Antioxidants including carotenoids, vitamin A and $\alpha$-tocopherol have been demonstrated in lung tissue samples and bronchoalveolar lavage fluids ${ }^{(92,93)}$, and supplementation with $\beta$-carotene has been shown to lead to increases in $\beta$-carotene concentrations in cells of bronchoalveolar lavage fluids ${ }^{(94)}$. As pointed out earlier, evidence points to inverse associations between intake and circulating concentrations of antioxidants and pulmonary function. In a trial of vegetable juice supplementation, young adults who received the vegetable juice rich in lycopene were found to experience significantly smaller reductions of FEV1 and FVC after a challenge with ozone compared with control participants ${ }^{(95)}$. Such potential protection could be important in adults with COPD whose respiratory reserve capacity is compromised. Lycopene has also been found to limit the inflammatory response exhibited by airway epithelial cells after a challenge with rhinovirus infection ${ }^{(96)}$. Because acute exacerbations of COPD due to respiratory infections result in excess mortality in adults with COPD, agents that could lessen the risk of respiratory infections or limit the damage caused by respiratory infections could possibly lead to reductions in mortality. However, a great deal of study is necessary to test the effects of antioxidant supplements on morbidity and mortality among adults with obstructive lung function. 
Table 5. Baseline adjusted mean concentrations of antioxidants associated with all-cause mortality among US adults aged 20-79 years with obstructive lung function, by race or ethnicity, National Health and Nutrition Examination Survey III Linked Mortality File 1988-94 to $2006^{\star}$

(Mean values with their standard errors; adjusted hazard ratios and $95 \%$ confidence intervals)

\begin{tabular}{|c|c|c|c|c|c|c|c|c|c|c|}
\hline & \multicolumn{3}{|c|}{ White ( $n 903,388$ deaths) } & \multicolumn{3}{|c|}{ African American ( $n 315,138$ deaths) } & \multicolumn{2}{|c|}{$\begin{array}{l}\text { Mexican American } \\
\text { ( } n \text { 232, } 92 \text { deaths) }\end{array}$} & & \multirow[b]{2}{*}{$P$-adjusted Wald $F$} \\
\hline & Mean & SE & & Mean & SE & & Mean & SE & & \\
\hline$\alpha$-Carotene $(\mu \mathrm{mol} / \mathrm{l})$ & 0.09 & 0.00 & & 0.07 & 0.01 & & 0.11 & 0.01 & & 0.002 \\
\hline$\beta$-Carotene $(\mu \mathrm{mol} / \mathrm{l})$ & 0.29 & 0.01 & & 0.29 & 0.02 & & 0.32 & 0.02 & & 0.470 \\
\hline Cryptoxanthin $(\mu \mathrm{mol} / \mathrm{l})$ & 0.16 & 0.00 & & 0.17 & 0.01 & & 0.29 & 0.02 & & $<0.001$ \\
\hline Lutein/zeaxanthin $(\mu \mathrm{mol} / \mathrm{l})$ & 0.34 & 0.01 & & 0.43 & 0.02 & & 0.45 & 0.03 & & $<0.001$ \\
\hline Lycopene $(\mu \mathrm{mol} / \mathrm{l})$ & 0.35 & 0.01 & & 0.31 & 0.01 & & 0.33 & 0.02 & & 0.045 \\
\hline Total carotenoids $(\mu \mathrm{mol} / \mathrm{l})$ & 1.28 & 0.02 & & 1.36 & 0.05 & & 1.59 & 0.09 & & 0.001 \\
\hline $\mathrm{Se}(\mathrm{nmol} / \mathrm{l})$ & 1.61 & 0.02 & & 1.52 & 0.01 & & 1.62 & 0.02 & & $<0.001$ \\
\hline Vitamin C $(\mathrm{mmol} / \mathrm{l})$ & 38.70 & 1.34 & & 28.89 & 1.76 & & 41.96 & 2.52 & & $<0.001$ \\
\hline \multirow[t]{2}{*}{ Vitamin $E(\mu \mathrm{mol} / /)^{\prime}$} & $27 \cdot 70$ & 0.37 & & $25 \cdot 54$ & 0.55 & & $28 \cdot 56$ & 1.00 & & $<0.001$ \\
\hline & Hazard ratio & $95 \% \mathrm{Cl}$ & $P$ & Hazard ratio & $95 \% \mathrm{Cl}$ & $P$ & Hazard ratio & $95 \% \mathrm{Cl}$ & $P$ & $P_{\text {interaction }}$ \\
\hline$\alpha$-Carotene $(\mu \mathrm{mol} / \mathrm{l})$ & 0.55 & $0.06,5.40$ & 0.598 & 0.09 & $0.00,17 \cdot 70$ & 0.359 & 0.02 & $0.00,7.52$ & 0.186 & 0.818 \\
\hline$\beta$-Carotene $(\mu \mathrm{mol} / \mathrm{l})$ & 0.91 & $0.73,1.14$ & 0.406 & 0.85 & $0.65,1.10$ & 0.212 & 0.75 & $0.51,1.12$ & 0.154 & 0.582 \\
\hline Cryptoxanthin $(\mu \mathrm{mol} / \mathrm{l})$ & 0.40 & $0.10,1.54$ & 0.176 & 0.15 & $0.01,4.04$ & 0.251 & 0.59 & $0.11,3.19$ & 0.531 & 0.927 \\
\hline Lutein/zeaxanthin $(\mu \mathrm{mol} / \mathrm{l})$ & 0.88 & $0.66,1.16$ & 0.362 & 0.55 & $0.36,0.85$ & 0.008 & 0.71 & $0.35,1.45$ & 0.344 & 0.324 \\
\hline Lycopene $(\mu \mathrm{mol} / \mathrm{l})$ & 0.75 & $0.63,0.90$ & 0.003 & 1.34 & $0.96,1.87$ & 0.082 & 0.69 & $0.41,1.16$ & 0.162 & 0.010 \\
\hline Total carotenoids $(\mu \mathrm{mol} / \mathrm{l})$ & 0.75 & $0.55,1.03$ & 0.076 & 0.71 & $0.42,1.21$ & 0.204 & 0.58 & $0.34,0.98$ & 0.042 & 0.377 \\
\hline $\mathrm{Se}(\mathrm{nmol} / \mathrm{l})$ & 0.98 & $0.50,1.92$ & 0.942 & 0.73 & $0.26,2.09$ & 0.553 & 0.36 & $0.12,1.08$ & 0.067 & 0.548 \\
\hline Vitamin $C(\mathrm{mmol} / \mathrm{l})$ & 0.95 & $0.90,1.00$ & 0.065 & 1.01 & $0.92,1.12$ & 0.775 & 0.91 & $0.81,1.03$ & 0.122 & 0.095 \\
\hline Vitamin E $(\mu \mathrm{mol} / \mathrm{l})$ & 1.03 & $0.66,1.60$ & 0.909 & 0.59 & $0.20,1.73$ & 0.328 & 0.44 & $0.12,1.64$ & 0.217 & 0.355 \\
\hline
\end{tabular}

* Log transformations for the concentrations of $\beta$-carotene, lutein/zeaxanthin, lycopene, total carotenoids and vitamin E. Square root transformation for the concentration of vitamin C. Adjusted for age, sex, education, smoking status, alcohol consumption, leisure-time physical activity, use of vitamin or mineral supplements, systolic blood pressure, HDL-cholesterol, non-HDL-cholesterol, BMI, C-reactive protein, albumin:creatinine ratio, health status, diabetes, history of myocardial infarction and history of stroke. 
Table 6. Baseline adjusted mean concentrations of antioxidants associated with all-cause mortality among US adults aged $20-79$ years with obstructive lung function, by smoking status, National Health and Nutrition Examination Survey III Linked Mortality File 1988-94 to 2006

(Mean values with their standard errors; adjusted hazard ratios and $95 \%$ confidence intervals)

\begin{tabular}{|c|c|c|c|c|c|c|c|c|c|c|}
\hline & \multicolumn{3}{|c|}{ Current ( $n 560,254$ deaths) } & \multicolumn{3}{|c|}{ Former ( $n 543,252$ deaths) } & \multicolumn{3}{|c|}{ Never ( $n 389,123$ deaths) } & \multirow[b]{2}{*}{$P$-adjusted Wald $F$} \\
\hline & Mean & SE & & Mean & SE & & Mean & SE & & \\
\hline$\alpha$-Carotene $(\mu \mathrm{mol} / \mathrm{l})$ & 0.07 & $<0.01$ & & $0 \cdot 10$ & $<0.01$ & & 0.11 & 0.01 & & $<0.001$ \\
\hline$\beta$-Carotene $(\mu \mathrm{mol} / \mathrm{l})$ & 0.23 & 0.01 & & 0.31 & 0.02 & & 0.36 & 0.02 & & $<0.001$ \\
\hline Cryptoxanthin $(\mu \mathrm{mol} / \mathrm{l})$ & 0.12 & 0.00 & & 0.17 & 0.01 & & 0.19 & 0.01 & & $<0.001$ \\
\hline Lutein/zeaxanthin $(\mu \mathrm{mol} / \mathrm{l})$ & 0.30 & 0.01 & & 0.37 & 0.01 & & 0.39 & 0.01 & & $<0.001$ \\
\hline Lycopene $(\mu \mathrm{mol} / \mathrm{l})$ & 0.32 & 0.01 & & 0.35 & 0.01 & & 0.37 & 0.01 & & 0.017 \\
\hline Total carotenoids $(\mu \mathrm{mol} / \mathrm{l})$ & $1 \cdot 10$ & 0.03 & & 1.37 & 0.04 & & 1.51 & 0.04 & & $<0.001$ \\
\hline $\mathrm{Se}(\mathrm{nmol} / \mathrm{l})$ & 1.56 & 0.02 & & 1.63 & 0.02 & & 1.63 & 0.02 & & 0.001 \\
\hline Vitamin $C(\mathrm{mmol} / \mathrm{l})$ & 30.05 & 1.66 & & $40 \cdot 63$ & 1.79 & & $46 \cdot 39$ & $2 \cdot 38$ & & $<0.001$ \\
\hline \multirow[t]{2}{*}{ Vitamin $E(\mu \mathrm{mol} / \mathrm{l})$} & $26 \cdot 56$ & 0.37 & & $27 \cdot 66$ & 0.41 & & $28 \cdot 62$ & 0.62 & & $<0.001$ \\
\hline & Hazard ratio & $95 \% \mathrm{Cl}$ & $P$ & Hazard ratio & $95 \% \mathrm{Cl}$ & $P$ & Hazard ratio & $95 \% \mathrm{Cl}$ & $P$ & $P_{\text {interaction }}$ \\
\hline$\alpha$-Carotene $(\mu \mathrm{mol} / \mathrm{l})$ & 0.30 & $0.00,36.44$ & 0.614 & $2 \cdot 34$ & $0.16,33.90$ & 0.527 & 0.11 & $0.00,8.31$ & 0.314 & 0.293 \\
\hline$\beta$-Carotene $(\mu \mathrm{mol} / \mathrm{l})$ & $0 \cdot 81$ & $0.64,1.02$ & 0.072 & 0.97 & $0.77,1.23$ & 0.827 & 0.98 & $0.64,1.50$ & 0.918 & 0.141 \\
\hline Cryptoxanthin $(\mu \mathrm{mol} / \mathrm{l})$ & 0.03 & $0.00,1.15$ & 0.059 & 0.51 & $0.16,1.59$ & 0.238 & 1.30 & $0.05,31.04$ & 0.868 & 0.285 \\
\hline Lutein/zeaxanthin $(\mu \mathrm{mol} / \mathrm{l})$ & 0.62 & $0.46,0.83$ & 0.002 & 1.03 & $0.71,1.48$ & 0.894 & 1.54 & $0.78,3.04$ & 0.207 & 0.048 \\
\hline Lycopene $(\mu \mathrm{mol} / \mathrm{l})$ & 0.73 & $0.59,0.91$ & 0.005 & 0.78 & $0.61,1.00$ & 0.053 & 0.78 & $0.52,1 \cdot 18$ & 0.236 & 0.536 \\
\hline Total carotenoids $(\mu \mathrm{mol} / \mathrm{l})$ & 0.56 & $0.38,0.83$ & 0.004 & 0.86 & $0.59,1.26$ & 0.434 & $1 \cdot 17$ & $0.63,2 \cdot 16$ & 0.614 & 0.141 \\
\hline $\mathrm{Se}(\mathrm{nmol} / \mathrm{l})$ & 0.96 & $0.30,3.00$ & 0.936 & 0.57 & $0.25,1.27$ & 0.163 & 4.45 & $1.37,14.43$ & 0.014 & 0.266 \\
\hline Vitamin $C(\mathrm{mmol} / \mathrm{l})$ & 0.94 & $0.87,1.02$ & 0.129 & 0.95 & $0.87,1.03$ & 0.219 & 0.98 & $0.82,1.18$ & 0.864 & 0.681 \\
\hline Vitamin E $(\mu \mathrm{mol} / \mathrm{l})$ & 0.64 & $0.27,1.48$ & 0.288 & 0.96 & $0.59,1.56$ & 0.871 & $2 \cdot 32$ & $0.71,7.58$ & 0.158 & 0.207 \\
\hline
\end{tabular}

* Log transformations for the concentrations of $\beta$-carotene, lutein/zeaxanthin, lycopene, total carotenoids and vitamin E. Square root transformation for the concentration of vitamin C. Means were back-transformed. Adjusted for age, sex, race or ethnicity, education, alcohol consumption, leisure-time physical activity, use of vitamin or mineral supplements, systolic blood pressure, HDL-cholesterol, non-HDL-cholesterol, BMI, C-reactive protein, albumin: creatinine ratio, health status, diabetes, history of myocardial infarction and history of stroke. Estimates for each antioxidant were not adjusted for the concentrations of other antioxidants. 
Vitamin C, which is a water-soluble essential vitamin, is involved in numerous physiological processes critical to maintaining internal homeostasis of the human body. Besides acting as a cofactor in various enzymatic reactions, it serves as an important antioxidant scavenging both reactive oxygen species and reactive $\mathrm{N}$ species ${ }^{(97)}$.

Observational prospective studies suggest that the intake and circulating concentrations of vitamin $\mathrm{C}$ are inversely associated with all-cause mortality or cause-specific mortality from leading chronic conditions ${ }^{(45-47,68,71,73,98-104)}$. In other observational studies, however, vitamin $\mathrm{C}$ intake was found to have no apparent effect on mortality ${ }^{(52,62,75,78,105-107)}$, and a systematic review concluded that supplementation with vitamin $\mathrm{C}$ has no beneficial effects on mortality ${ }^{(77)}$. We are not aware of studies that have examined the effect of circulating concentrations of vitamin $\mathrm{C}$ on mortality among adults with obstructive lung function.

The prevalence of cigarette smoking is high among adults with obstructive lung function. In the present study, about $44 \%$ of the participants reported being current smokers. Consequently, the excess mortality among adults with COPD is in part attributable to the high prevalence of smoking. Because smoking is a prime source of oxidative stress, bolstering antioxidant defences through supplementation with antioxidants could potentially mitigate some of the ravages from smoking-induced damage to the lungs and the downstream adverse effects of oxidative stress. It has been suggested by two large trials of supplementation with $\beta$-carotene and $\alpha$-tocopherol in smokers and $\beta$-carotene and retinyl palmitate in participants who had been exposed to asbestos or were heavy smokers that yielded negative consequences for the experimental groups that caution needs to be exercised while extrapolating the findings of observational studies to recommendations for using antioxidant supplementation as an approach to primary or secondary prevention ${ }^{(108,109)}$. The results of the present study did not show that the concentrations of $\beta$-carotene and vitamin $\mathrm{E}$ in current smokers were significantly associated with all-cause mortality.

The results of the present study should be viewed in the context of several limitations. A larger sample size would have provided additional statistical power to detect significant associations, to examine the associations between antioxidant concentrations and mortality in separate groups of participants with mild, moderate, and severe obstructive lung function, and to examine associations between antioxidant concentrations and cause-specific mortality. The concentrations of antioxidants were measured at a single point in time and may not have represented the usual concentrations of the study participants. Concentration data of only $\alpha$-tocopherol were available in NHANES III. Interest in the health effects of $\gamma$-tocopherol has grown, and future investigations into the association between $\gamma$-tocopherol concentrations and mortality in adults with obstructive lung function would be of interest. Although a substantial number of covariates were included in the analyses, residual confounding remains a possibility as in most observational studies.

In conclusion, the concentrations of lycopene and vitamin $\mathrm{C}$ were inversely associated with all-cause mortality among adults with obstructive lung function. The failure of trials of $\beta$-carotene and $\alpha$-tocopherol supplementation in smokers to show benefits and of antioxidant supplementation in trials of secondary prevention suggest that caution needs to be exercised before recommending antioxidant supplementation in patients with COPD. Because limited studies have examined the associations between circulating concentrations of antioxidants and all-cause mortality and cause-specific mortality in adults with COPD, additional studies in this area are needed. In addition, studies examining the intake of antioxidants from diet and supplements in adults with COPD may also yield valuable data. Lastly, trials of antioxidant supplementation in patients with COPD may be needed to fully gauge the beneficial or harmful effects of antioxidant supplementation on complications from COPD. Regardless, physicians may evaluate the nutritional status of their patients with COPD and their diets and make recommendations consistent with current dietary recommendations.

\section{Acknowledgements}

The authors' contributions are as follows: E. S. F. conceived the study; E. S. F. and C. L. participated in the design and conduct of the study; E. S. F. conducted the analyses and drafted the manuscript; T. J. C. and J. B. C. contributed to the analysis, interpretation, and critical revision of the manuscript. All authors approved the final manuscript.

The authors declare no personal or financial interests.

\section{References}

1. Mannino DM \& Buist AS (2007) Global burden of COPD: risk factors, prevalence, and future trends. Lancet 370, $765-773$

2. Lozano R, Naghavi M, Foreman K, et al. (2012) Global and regional mortality from 235 causes of death for 20 age groups in 1990 and 2010: a systematic analysis for the Global Burden of Disease Study 2010. Lancet 380, 2095-2128.

3. Ford ES, Croft JB, Mannino DM, et al. (2013) COPD surveillance - United States, 1999-2011. Chest 144, 284-305.

4. Strachan DP, Cox BD, Erzinclioglu SW, et al. (1991) Ventilatory function and winter fresh fruit consumption in a random sample of British adults. Thorax 46, 624-629.

5. Miedema I, Feskens EJ, Heederik D, et al. (1993) Dietary determinants of long-term incidence of chronic nonspecific lung diseases. The Zutphen Study. Am J Epidemiol 138, $37-45$.

6. Ness AR, Khaw KT, Bingham S, et al. (1996) Vitamin C status and respiratory function. Eur I Clin Nutr 50, 573-579.

7. Carey IM, Strachan DP \& Cook DG (1998) Effects of changes in fresh fruit consumption on ventilatory function in healthy British adults. Am J Respir Crit Care Med 158, $728-733$

8. La Vecchia C, Decarli A \& Pagano R (1998) Vegetable consumption and risk of chronic disease. Epidemiology 9, 208-210.

9. Tabak C, Smit HA, Rasanen L, et al. (1999) Dietary factors and pulmonary function: a cross sectional study in middle aged men from three European countries. Thorax 54, 1021-1026. 
10. Tabak C, Smit HA, Heederik D, et al. (2001) Diet and chronic obstructive pulmonary disease: independent beneficial effects of fruits, whole grains, and alcohol (the MORGEN study). Clin Exp Allergy 31, 747-755.

11. Watson L, Margetts B, Howarth $\mathrm{P}$, et al. (2002) The association between diet and chronic obstructive pulmonary disease in subjects selected from general practice. Eur Respir J 20, 313-318.

12. Kelly Y, Sacker A \& Marmot M (2003) Nutrition and respiratory health in adults: findings from the health survey for Scotland. Eur Respir J 21, 664-671.

13. Romieu I (2005) Nutrition and lung health. Int J Tuberc Lung Dis 9, 362-374.

14. Hirayama F, Lee AH, Binns CW, et al. (2009) Do vegetables and fruits reduce the risk of chronic obstructive pulmonary disease? A case-control study in Japan. Prev Med 49, 184-189.

15. Schwartz J \& Weiss ST (1994) Relationship between dietary vitamin $\mathrm{C}$ intake and pulmonary function in the First National Health and Nutrition Examination Survey (NHANES I). Am J Clin Nutr 59, 110-114.

16. Britton JR, Pavord ID, Richards KA, et al. (1995) Dietary antioxidant vitamin intake and lung function in the general population. Am J Respir Crit Care Med 151, 1383-1387.

17. Hu G, Zhang X, Chen J, et al. (1998) Dietary vitamin C intake and lung function in rural China. Am J Epidemiol 148, 594-599.

18. Grievink L, Smit HA, Ocke MC, et al. (1998) Dietary intake of antioxidant (pro)-vitamins, respiratory symptoms and pulmonary function: the MORGEN study. Thorax 53, 166-171.

19. Chen R, Tunstall-Pedoe H, Bolton-Smith C, et al. (2001) Association of dietary antioxidants and waist circumference with pulmonary function and airway obstruction. $A m$ J Epidemiol 153, 157-163.

20. Dow L, Tracey M, Villar A, et al. (1996) Does dietary intake of vitamins $\mathrm{C}$ and $\mathrm{E}$ influence lung function in older people? Am J Respir Crit Care Med 154, 1401-1404.

21. Schunemann HJ, McCann S, Grant BJ, et al. (2002) Lung function in relation to intake of carotenoids and other antioxidant vitamins in a population-based study. Am $J$ Epidemiol 155, 463-471.

22. Chuwers P, Barnhart S, Blanc P, et al. (1997) The protective effect of $\beta$-carotene and retinol on ventilatory function in an asbestos-exposed cohort. Am J Respir Crit Care Med 155, 1066-1071.

23. Van Antwerpen VL, Theron AJ, Richards GA, et al. (1995) Relationship between the plasma levels of $\beta$-carotene and lung functions in cigarette smokers. Int J Vitam Nutr Res 65, 231-235.

24. Grievink L, Smit HA, van't Veer P, et al. (1999) Plasma concentrations of the antioxidants $\beta$-carotene and $\alpha$-tocopherol in relation to lung function. Eur J Clin Nutr 53, 813-817.

25. Grievink L, de Waart FG, Schouten EG, et al. (2000) Serum carotenoids, $\alpha$-tocopherol, and lung function among Dutch elderly. Am J Respir Crit Care Med 161, 790-795.

26. Hu G \& Cassano PA (2000) Antioxidant nutrients and pulmonary function: the Third National Health and Nutrition Examination Survey (NHANES III). Am J Epidemiol 151, 975-981.

27. Schunemann HJ, Grant BJ, Freudenheim JL, et al. (2001) The relation of serum levels of antioxidant vitamins $\mathrm{C}$ and E, retinol and carotenoids with pulmonary function in the general population. Am J Respir Crit Care Med 163, $1246-1255$.

28. Ochs-Balcom HM, Grant BJ, Muti P, et al. (2006) Antioxidants, oxidative stress, and pulmonary function in individuals diagnosed with asthma or COPD. Eur J Clin Nutr 60, 991-999.

29. McKeever TM, Lewis SA, Smit HA, et al. (2008) A multivariate analysis of serum nutrient levels and lung function. Respir Res 9, 67-69.

30. Lin YC, Wu TC, Chen PY, et al. (2010) Comparison of plasma and intake levels of antioxidant nutrients in patients with chronic obstructive pulmonary disease and healthy people in Taiwan: a case-control study. Asia Pac J Clin Nutr 19, 393-401.

31. Semba RD, Chang SS, Sun K, et al. (2012) Serum carotenoids and pulmonary function in older community-dwelling women. J Nutr Health Aging 16, 291-296.

32. Alfonso HS, Fritschi L, de Klerk NH, et al. (2005) Plasma retinol, carotene and vitamin E concentrations and lung function in a crocidolite-exposed cohort from Wittenoom, Western Australia: a cohort study. Nutr J 4, 16.

33. Guenegou A, Leynaert B, Pin I, et al. (2006) Serum carotenoids, vitamins $\mathrm{A}$ and $\mathrm{E}$, and 8 year lung function decline in a general population. Thorax 61, 320-326.

34. Guenegou A, Boczkowski J, Aubier M, et al. (2008) Interaction between a heme oxygenase-1 gene promoter polymorphism and serum $\beta$-carotene levels on 8 -year lung function decline in a general population: the European Community Respiratory Health Survey (France). Am J Epidemiol 167, 139-144.

35. Tabak C, Feskens EJ, Heederik D, et al. (1998) Fruit and fish consumption: a possible explanation for population differences in COPD mortality (The Seven Countries Study). Eur J Clin Nutr 52, 819-825.

36. Walda IC, Tabak C, Smit HA, et al. (2002) Diet and 20-year chronic obstructive pulmonary disease mortality in middleaged men from three European countries. Eur J Clin Nutr 56, 638-643.

37. MacNee W (2000) Oxidants/antioxidants and COPD. Chest 117, 303S-317S.

38. Ochs-Balcom HM, Grant BJ, Muti P, et al. (2005) Oxidative stress and pulmonary function in the general population. Am J Epidemiol 162, 1137-1145.

39. Biswas S, Hwang JW, Kirkham PA, et al. (2013) Pharmacological and dietary antioxidant therapies for chronic obstructive pulmonary disease. Curr Med Chem 20, 1496-1530.

40. Centers for Disease Control and Prevention (1994) Plan and operation of the Third National Health and Nutrition Examination Survey, 1988-94. Vital Health Stat 1(32), 1-407.

41. Centers for Disease Control and Prevention (2013) NHANES III Linked Mortality File. http://www.cdc.gov/nchs/ data_access/data_linkage/mortality/nhanes3_linkage.htm (accessed 10 March 2014).

42. Westat, Inc. (1988) Third National Health and Nutrition Examination Survey. Spirometry Procedure Manual. http://www.cdc.gov/nchs/data/nhanes/nhanes3/cdrom/nchs/ manuals/spiro.pdf (accessed 24 July 2013).

43. Goyal A, Terry MB \& Siegel AB (2013) Serum antioxidant nutrients, vitamin A, and mortality in US adults. Cancer Epidemiol Biomarkers Prev 22, 2202-2211.

44. Akbaraly TN, Favier A \& Berr C (2009) Total plasma carotenoids and mortality in the elderly: results of the Epidemiology of Vascular Ageing (EVA) study. Br J Nutr 101, 86-92.

45. Stahelin HB, Gey KF, Eichholzer M, et al. (1991) Plasma antioxidant vitamins and subsequent cancer mortality in the 12-year follow-up of the prospective Basel Study. $\mathrm{Am}$ J Epidemiol 133, 766-775. 
46. Gey KF, Stahelin HB \& Eichholzer M (1993) Poor plasma status of carotene and vitamin $\mathrm{C}$ is associated with higher mortality from ischemic heart disease and stroke: Basel Prospective Study. Clin Investig 71, 3-6.

47. Eichholzer M, Stahelin HB, Gey KF, et al. (1996) Prediction of male cancer mortality by plasma levels of interacting vitamins: 17-year follow-up of the prospective Basel Study. Int J Cancer 66, 145-150.

48. Greenberg ER, Baron JA, Karagas MR, et al. (1996) Mortality associated with low plasma concentration of $\beta$ carotene and the effect of oral supplementation. JAMA 275, 699-703.

49. Ito Y, Suzuki S, Yagyu K, et al. (1997) Relationship between serum carotenoid levels and cancer death rates in the residents, living in a rural area of Hokkaido, Japan. $J$ Epidemiol 7, 1-8.

50. de Waart FG, Schouten EG, Stalenhoef AF, et al. (2001) Serum carotenoids, $\alpha$-tocopherol and mortality risk in a prospective study among Dutch elderly. Int J Epidemiol 30, 136-143.

51. Ito Y, Suzuki K, Suzuki S, et al. (2002) Serum antioxidants and subsequent mortality rates of all causes or cancer among rural Japanese inhabitants. Int J Vitam Nutr Res 72, 237-250

52. Fletcher AE, Breeze E \& Shetty PS (2003) Antioxidant vitamins and mortality in older persons: findings from the nutrition add-on study to the Medical Research Council Trial of Assessment and Management of Older People in the Community. Am J Clin Nutr 78, 999-1010.

53. Hu P, Reuben DB, Crimmins EM, et al. (2004) The effects of serum $\beta$-carotene concentration and burden of inflammation on all-cause mortality risk in high-functioning older persons: MacArthur studies of successful aging. J Gerontol A Biol Sci Med Sci 59, 849-854.

54. Kornitzer M, Valente F, De Bacquer D, et al. (2004) Serum selenium and cancer mortality: a nested case-control study within an age- and sex-stratified sample of the Belgian adult population. Eur J Clin Nutr 58, 98-104.

55. Buijsse B, Feskens EJ, Schlettwein-Gsell D, et al. (2005) Plasma carotene and $\alpha$-tocopherol in relation to $10-\mathrm{y}$ allcause and cause-specific mortality in European elderly: the Survey in Europe on Nutrition and the Elderly, a Concerted Action (SENECA). Am J Clin Nutr 82, 879-886.

56. Ray AL, Semba RD, Walston J, et al. (2006) Low serum selenium and total carotenoids predict mortality among older women living in the community: the women's health and aging studies. J Nutr 136, 172-176.

57. Ito Y, Kurata M, Hioki R, et al. (2005) Cancer mortality and serum levels of carotenoids, retinol, and tocopherol: a population-based follow-up study of inhabitants of a rural area of Japan. Asian Pac J Cancer Prev 6, 10-15.

58. Ito Y, Wakai K, Suzuki K, et al. (2005) Lung cancer mortality and serum levels of carotenoids, retinol, tocopherols, and folic acid in men and women: a case-control study nested in the JACC Study. J Epidemiol 15, Suppl. 2, S140-S149.

59. Ito Y, Suzuki K, Ishii J, et al. (2006) A population-based follow-up study on mortality from cancer or cardiovascular disease and serum carotenoids, retinol and tocopherols in Japanese inhabitants. Asian Pac J Cancer Prev 7, 533-546.

60. Ito Y, Kurata M, Suzuki K, et al. (2006) Cardiovascular disease mortality and serum carotenoid levels: a Japanese population-based follow-up study. $J$ Epidemiol 16, $154-160$

61. Wright ME, Lawson KA, Weinstein SJ, et al. (2006) Higher baseline serum concentrations of vitamin $\mathrm{E}$ are associated with lower total and cause-specific mortality in the Alpha-Tocopherol, Beta-Carotene Cancer Prevention Study. Am J Clin Nutr 84, 1200-1207.

62. Buijsse B, Feskens EJ, Kwape L, et al. (2008) Both $\alpha$ - and $\beta$-carotene, but not tocopherols and vitamin $C$, are inversely related to 15 -year cardiovascular mortality in Dutch elderly men. J Nutr 138, 344-350.

63. Lauretani F, Semba RD, Dayhoff-Brannigan M, et al. (2008) Low total plasma carotenoids are independent predictors of mortality among older persons: the InCHIANTI study. Eur J Nutr 47, 335-340.

64. Bates CJ, Hamer M \& Mishra GD (2011) Redox-modulatory vitamins and minerals that prospectively predict mortality in older British people: the National Diet and Nutrition Survey of people aged 65 years and over. Br J Nutr 105, $123-132$.

65. Shardell MD, Alley DE, Hicks GE, et al. (2011) Low-serum carotenoid concentrations and carotenoid interactions predict mortality in US adults: the Third National Health and Nutrition Examination Survey. Nutr Res 31, 178-189.

66. Li C, Ford ES, Zhao G, et al. (2011) Serum $\alpha$-carotene concentrations and risk of death among US Adults: the Third National Health and Nutrition Examination Survey Followup Study. Arch Intern Med 171, 507-515.

67. Karppi J, Laukkanen JA, Makikallio TH, et al. (2012) Low $\beta$-carotene concentrations increase the risk of cardiovascular disease mortality among Finnish men with risk factors. Nutr Metab Cardiovasc Dis 22, 921-928.

68. Sahyoun NR, Jacques PF \& Russell RM (1996) Carotenoids, vitamins $\mathrm{C}$ and $\mathrm{E}$, and mortality in an elderly population. Am J Epidemiol 144, 501-511.

69. Kilander L, Berglund L, Boberg M, et al. (2001) Education, lifestyle factors and mortality from cardiovascular disease and cancer. A 25-year follow-up of Swedish 50-year-old men. Int J Epidemiol 30, 1119-1126.

70. Kataja-Tuomola MK, Kontto JP, Mannisto S, et al. (2010) Effect of $\alpha$-tocopherol and $\beta$-carotene supplementation on macrovascular complications and total mortality from diabetes: results of the ATBC Study. Ann Med 42, 178-186.

71. Knekt P, Reunanen A, Jarvinen R, et al. (1994) Antioxidant vitamin intake and coronary mortality in a longitudinal population study. Am J Epidemiol 139, 1180-1189.

72. Gaziano JM, Manson JE, Branch LG, et al. (1995) A prospective study of consumption of carotenoids in fruits and vegetables and decreased cardiovascular mortality in the elderly. Ann Epidemiol 5, 255-260.

73. Agudo A, Cabrera L, Amiano P, et al. (2007) Fruit and vegetable intakes, dietary antioxidant nutrients, and total mortality in Spanish adults: findings from the Spanish cohort of the European Prospective Investigation into Cancer and Nutrition (EPIC-Spain). Am J Clin Nutr 85, 1634-1642.

74. Qiao YL, Dawsey SM, Kamangar F, et al. (2009) Total and cancer mortality after supplementation with vitamins and minerals: follow-up of the Linxian General Population Nutrition Intervention Trial. J Natl Cancer Inst 101, 507-518.

75. Genkinger JM, Platz EA, Hoffman SC, et al. (2004) Fruit, vegetable, and antioxidant intake and all-cause, cancer, and cardiovascular disease mortality in a communitydwelling population in Washington County, Maryland. Am J Epidemiol 160, 1223-1233.

76. Bardia A, Tleyjeh IM, Cerhan JR, et al. (2008) Efficacy of antioxidant supplementation in reducing primary cancer incidence and mortality: systematic review and metaanalysis. Mayo Clin Proc 83, 23-34. 
77. Bjelakovic G, Nikolova D, Gluud LL, et al. (2012) Antioxidant supplements for prevention of mortality in healthy participants and patients with various diseases. The Cochrane Database of Systematic Reviews 2012, issue 3 , CD007176.

78. Roswall N, Olsen A, Christensen J, et al. (2012) Micronutrient intake in relation to all-cause mortality in a prospective Danish cohort. Food Nutr Res 56, 5466

79. Vivekananthan DP, Penn MS, Sapp SK, et al. (2003) Use of antioxidant vitamins for the prevention of cardiovascular disease: meta-analysis of randomised trials. Lancet 361, $2017-2023$

80. Ito Y, Wakai K, Suzuki K, et al. (2003) Serum carotenoids and mortality from lung cancer: a case-control study nested in the Japan Collaborative Cohort (JACC) study. Cancer Sci 94, 57-63.

81. Bhuvaneswari V \& Nagini S (2005) Lycopene: a review of its potential as an anticancer agent. Curr Med Chem Anticancer Agents 5, 627-635.

82. Gallicchio L, Boyd K, Matanoski G, et al. (2008) Carotenoids and the risk of developing lung cancer: a systematic review. Am J Clin Nutr 88, 372-383.

83. Ford ES, Mannino DM, Zhao G, et al. (2012) Changes in mortality among US adults with COPD in two national cohorts recruited from 1971-1975 and 1988-1994. Chest 141, 101-110.

84. Karppi J, Laukkanen JA, Makikallio TH, et al. (2012) Low serum lycopene and $\beta$-carotene increase risk of acute myocardial infarction in men. Eur J Public Health 22, 835-840.

85. Karppi J, Laukkanen JA, Sivenius J, et al. (2012) Serum lycopene decreases the risk of stroke in men: a population-based follow-up study. Neurology 79, 1540-1547.

86. Jacques PF, Lyass A, Massaro JM, et al. (2013) Relationship of lycopene intake and consumption of tomato products to incident CVD. Br J Nutr 110, 545-551.

87. Di MP, Kaiser S \& Sies H (1989) Lycopene as the most efficient biological carotenoid singlet oxygen quencher. $A r c h$ Biochem Biophys 274, 532-538.

88. Hung CF, Huang TF, Chen BH, et al. (2008) Lycopene inhibits TNF- $\alpha$-induced endothelial ICAM-1 expression and monocyte-endothelial adhesion. Eur J Pharmacol 586, $275-282$

89. Armoza A, Haim Y, Bashiri A, et al. (2013) Tomato extract and the carotenoids lycopene and lutein improve endothelial function and attenuate inflammatory NF- $\mathrm{KB}$ signaling in endothelial cells. J Hypertens 31, 521-529.

90. McEneny J, Wade L, Young IS, et al. (2013) Lycopene intervention reduces inflammation and improves HDL functionality in moderately overweight middle-aged individuals. J Nutr Biochem 24, 163-168.

91. Palozza P, Simone RE, Catalano A, et al. (2012) Modulation of MMP-9 pathway by lycopene in macrophages and fibroblasts exposed to cigarette smoke. Inflamm Allergy Drug Targets 11, 36-47.

92. Schmitz HH, Poor CL, Wellman RB, et al. (1991) Concentrations of selected carotenoids and vitamin A in human liver, kidney and lung tissue. J Nutr 121, 1613-1621.

93. Redlich CA, Grauer JN, Van Bennekum AM, et al. (1996) Characterization of carotenoid, vitamin A, and $\alpha$-tocopherol levels in human lung tissue and pulmonary macrophages. Am J Respir Crit Care Med 154, 1436-1443.
94. Redlich CA, Blaner WS, Van Bennekum AM, et al. (1998) Effect of supplementation with $\beta$-carotene and vitamin A on lung nutrient levels. Cancer Epidemiol Biomarkers Prev 7, 211-214.

95. Samet JM, Hatch GE, Horstman D, et al. (2001) Effect of antioxidant supplementation on ozone-induced lung injury in human subjects. Am J Respir Crit Care Med $\mathbf{1 6 4}$ 819-825.

96. Saedisomeolia A, Wood LG, Garg ML, et al. (2009) Lycopene enrichment of cultured airway epithelial cells decreases the inflammation induced by rhinovirus infection and lipopolysaccharide. J Nutr Biochem 20, 577-585.

97. Institute of Medicine (2000) Dietary Reference Intakes for Vitamin C, Vitamin E, Selenium, and Carotenoids. Washington, DC: The National Academies Press.

98. Simon JA, Hudes ES \& Tice JA (2001) Relation of serum ascorbic acid to mortality among US adults. J Am Coll Nutr 20, 255-263.

99. Hodkinson HM \& Exton-Smith AN (1976) Factors predicting mortality in the elderly in the community. Age Ageing $\mathbf{5}$ $110-115$.

100. Enstrom JE, Kanim LE \& Klein MA (1992) Vitamin C intake and mortality among a sample of the United States population. Epidemiology 3, 194-202.

101. Hensrud DD, Heimburger DC, Chen J, et al. (1994) Antioxidant status, erythrocyte fatty acids, and mortality from cardiovascular disease and Keshan disease in China. Eur J Clin Nutr 48, 455-464.

102. Loria CM, Klag MJ, Caulfield LE, et al. (2000) Vitamin C status and mortality in US adults. Am J Clin Nutr $\mathbf{7 2}$ 139-145.

103. Khaw KT, Bingham S, Welch A, et al. (2001) Relation between plasma ascorbic acid and mortality in men and women in EPIC-Norfolk prospective study: a prospective population study. European Prospective Investigation into Cancer and Nutrition. Lancet 357, 657-663.

104. Jia X, Aucott LS \& McNeill G (2007) Nutritional status and subsequent all-cause mortality in men and women aged 75 years or over living in the community. Br J Nutr $\mathbf{9 8}$, 593-599.

105. Enstrom JE, Kanim LE \& Breslow L (1986) The relationship between vitamin $\mathrm{C}$ intake, general health practices, and mortality in Alameda County, California. Am J Public Health 76, 1124-1130.

106. Jacobs EJ, Henion AK, Briggs PJ, et al. (2002) Vitamin C and vitamin $\mathrm{E}$ supplement use and bladder cancer mortality in a large cohort of US men and women. Am J Epidemiol 156, $1002-1010$

107. Jacobs EJ, Connell CJ, McCullough ML, et al. (2002) Vitamin C, vitamin E, and multivitamin supplement use and stomach cancer mortality in the Cancer Prevention Study II cohort. Cancer Epidemiol Biomarkers Prev 11, $35-41$.

108. The Alpha-Tocopherol, Beta Carotene Cancer Prevention Study Group (1994) The effect of vitamin E and $\beta$ carotene on the incidence of lung cancer and other cancers in male smokers. $N$ Engl J Med 330, 1029-1035.

109. Omenn GS, Goodman GE, Thornquist MD, et al. (1996) Effects of a combination of $\beta$ carotene and vitamin $A$ on lung cancer and cardiovascular disease. $N$ Engl J Med 334, 1150-1155. 